\title{
Lake ice ablation rates from permanently ice-covered Antarctic lakes
}

\author{
H.A. DUGAN, M.K. OBRYK, P.T. DORAN \\ Department of Earth and Environmental Sciences, University of Illinois at Chicago, Chicago, IL, USA \\ E-mail: hilarydugan@gmail.com
}

\begin{abstract}
In the McMurdo Dry Valleys of Antarctica, three large, permanently ice-covered, closedbasin lakes exist along the floor of Taylor Valley. Lake ice ablation (loss of ice mass) is calculated as the sum of sublimation and surface melt, and is the driver of ice-cover turnover in these systems. In Taylor Valley, both manual and automated lake ice ablation rates have been calculated from 2001 to 2011. Results indicate relatively consistent winter ablation of $0.07-0.21 \mathrm{~m}\left(0.2-0.7 \mathrm{~mm} \mathrm{w.e.} \mathrm{d}^{-1}\right)$. Summer

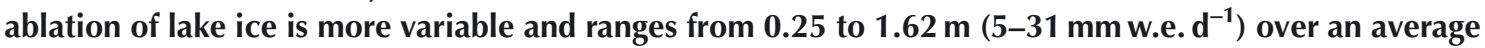
51 day period. Previous to this study, ablation rates have been cited as $0.35 \mathrm{~m} \mathrm{a}^{-1}$ in the dry valleys from sublimation modeling based on meteorological variables. We show that this value has significantly underestimated mean ablation and ice-cover turnover on the Taylor Valley lakes.
\end{abstract}

\section{INTRODUCTION}

Throughout the winter, most lakes located at high latitudes and altitudes develop a seasonal ice cover. During this period, and in the absence of an outflow, loss of water from the lakes is governed by ice sublimation, the phase change of ice directly to water vapor. Sublimation, like evaporation, is difficult to quantify empirically (Box and Steffen, 2001), and is often neglected in hydrological budgets or assumed to be a very small fraction of overall water loss (Woo, 1980). Modeling sublimation is possible, but necessitates the measurement of many climate variables and local ice conditions. Often, surface roughness and surface temperature must themselves be modeled, and albedo estimated, which compounds the associated error on final sublimation rates (McKay and others, 1985; Clow and others, 1988; Brock and Arnold, 2000; Bliss and others, 2011). Furthermore, the transience of most lake ice prevents the year-round installation of massbalance stakes, which are typically used in glacial settings to manually record ice loss (Heron and Woo, 1994).

In the McMurdo Dry Valleys of Antarctica, three large, permanently ice-covered, closed-basin lakes are located along the floor of Taylor Valley. The persistence of a yearround ice cover provides a stable platform and an ideal environment for empirically measuring the overall rate of ablation (ice loss) and sublimation (the transformation of ice to water vapor, which is lost from the system). In this extreme desert ecosystem, lake volumes are regulated almost solely by gain from glacially fed streams and direct glacial melt, and mass loss through sublimation (Chinn, 1993; Doran and others, 1994). Gain from snowfall and loss through the evaporation of liquid water at the lake edges are minor components. The only assessment of groundwater in the region is in association with the 1972-74 Dry Valleys Drilling Project. Boreholes at Lake Hoare and to the east of Lake Fryxell did not exhibit water level fluctuations or geothermal displacement of drilling fluid, which suggests an absence of subsurface flow (Harris and Cartwright, 1981). During the dark austral winter, the negative water balance of the lakes reflects the sublimation of lake ice. In the summer, ablation of ice results from both surface sublimation and surface melt. It is important to note that ice melt, where water is assumed to drain downward into the lake (and not remain as inclusions in the ice), does not alter lake volume, as no water is lost from the system.

In this paper, we discuss 10 years of winter sublimation and annual ablation rates from three large lakes in the McMurdo Dry Valleys. From 2001 to 2011, the levels of Lakes Fryxell, Hoare and Bonney have risen rapidly (Barrett and others, 2008). Accurately quantifying ablation and sublimation rates is critical for closing the hydrological balance in the dry valleys, where sublimation is the fundamental control on water loss in this desert ecosystem. The longevity of this dataset is unequaled, and results should be used to corroborate modeled sublimation in this and other lacustrine settings.

\section{SITE DESCRIPTION}

The McMurdo Dry Valleys receive only 3-50 mm of annual snowfall due to a precipitation shadow effect produced along the Transantarctic Mountains to the south, and, as a result, are one of the few non-glacierized regions of Antarctica (Monaghan and others, 2005; Fountain and others, 2010). In Taylor Valley, three large lakes, Lakes Bonney $\left(4.3 \mathrm{~km}^{2}\right)$, Hoare $\left(2.2 \mathrm{~km}^{2}\right)$ and Fryxell $\left(6.7 \mathrm{~km}^{2}\right)$, are situated from west to east along the valley floor (Fig. 1). Lake Bonney is separated into two basins by a shallow sill and is commonly referred to as two bodies of water: East Lobe and West Lobe Bonney.

The lakes have distinct climates as a result of their position in the valley. Lake Fryxell, which lies adjacent to the coast, has the lowest mean annual temperature and highest annual precipitation (Table 1; Doran and others, 2002a; Fountain and others, 2010). Lake Hoare has the lowest mean annual wind speed, as it is relatively sheltered from easterly coastal winds by Canada Glacier, and westerly winds by Seuss Glacier and Nussbaum Riegel (Fig. 1; Doran and others, 2002a; Monaghan and others, 2005). Lake Bonney is the warmest and windiest of the three lakes, with a climate that is largely moderated by westerly winds which surge off Taylor Glacier (Nylen and others, 2004). These winds increase air temperatures throughout the valley, but are especially noticeable and frequent at Lake Bonney, which is closest to the polar plateau. 


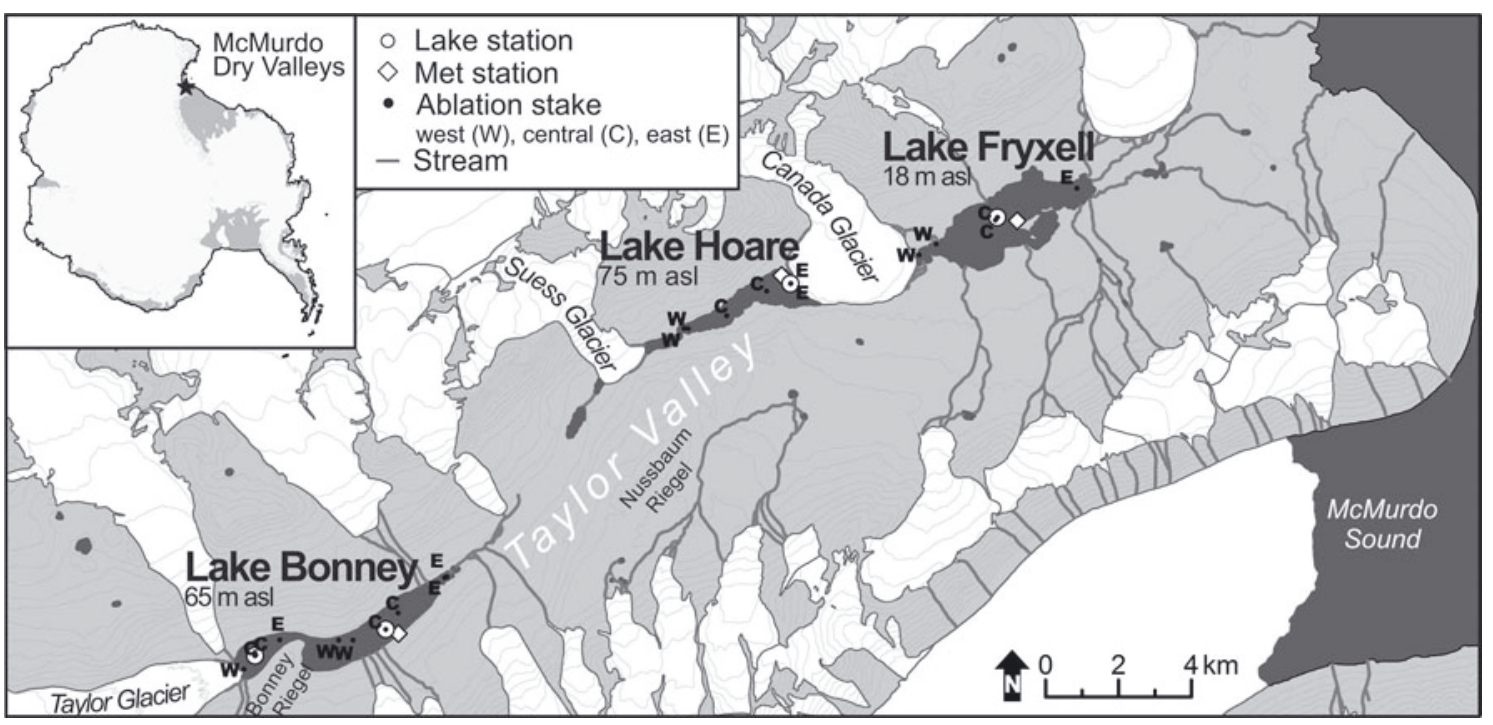

Fig. 1. The location of ablation stakes, lake stations and meteorological stations at Lakes Bonney, Hoare and Fryxell in Taylor Valley, Antarctica. Contour interval is $100 \mathrm{~m}$.

All lakes are permanently covered with $3-6 \mathrm{~m}$ of ice, and have no outlets (Priscu and others, 1998; Doran and others, 2002b). The lake ice acts as an upward conveyor belt through time, as bottom ice slowly becomes surface ice as the topmost layers ablate. During the summer, ice covers typically thin $<1.5 \mathrm{~m}$ (P. Doran and J. Priscu, unpublished data), and narrow moats of liquid water develop around the edges of the lakes; however, open water accounts for only a small percentage of the total surface area. Sediment is frequently blown onto the lake surfaces by strong winds and can accumulate in hollows. The enhanced melt associated with sediment pockets is likely the origin of the rough surface ice (Fig. 2; Simmons and others, 1986; Squyres and others, 1991).

\section{METHODS}

Automated lake stations are situated in the center of Lake Fryxell, East and West Lobe Bonney and the eastern side of Lake Hoare (Fig. 1). A data logger housed on the ice surface records the depth of two pressure transducers. A moored pressure transducer is used to calculate stage, and is affixed to a floating buoy weighted to the lake bottom (Fig. 3a). The second pressure transducer is suspended from the ice on a cable, which is affixed with short sections of PVC to act as ice anchors, and moves upward through the water column as the ice ablates (Fig. 3a). Ablation values are calculated as the change in depth of the hanging pressure transducer. As the depth is relative, ablation values are reset to a zero baseline following an extended sensor failure (Fig. 4a and b).

The depths of the moored and hanging transducers are affected by all processes that alter the volume of the lake, and the thickness of the surface ice, respectively (Fig. 3b).

$$
\begin{aligned}
& \text { depth of moored transducer (stage) } \\
& =\text { glacial/river inflow + snowfall }- \text { sublimation } \\
& \quad-\text { evaporation }
\end{aligned}
$$

depth of hanging transducer (ablation)

$$
\begin{aligned}
= & \text { ice surface (snowfall }- \text { ablation) } \\
& + \text { ice bottom (melt }- \text { growth) }
\end{aligned}
$$

When ice accretes onto the bottom of the ice cover during winter, the ice cover is buoyantly displaced upwards by a factor proportional to the thickness of new ice multiplied by the density contrast between the ice and water. This artificially raises ablation values as the sensor is moved higher in the water column. To avoid erroneously high winter values, stage is used in lieu of ablation during the winter when calculating absolute rates of sublimation. The limited snowfall in Taylor Valley does add surface mass to the lake ice covers, but is extremely heterogeneous and

\begin{tabular}{|c|c|c|c|c|c|c|c|c|c|}
\hline & \multicolumn{3}{|c|}{2010 mean annual } & \multicolumn{3}{|c|}{ Dec-Jan mean } & \multicolumn{3}{|c|}{ Feb-Nov mean } \\
\hline & LF & $\mathrm{LH}$ & LB & LF & $\mathrm{LH}$ & LB & LF & $\mathrm{LH}$ & LB \\
\hline Air temperature $\left({ }^{\circ} \mathrm{C}\right)$ & -20.8 & -18.2 & -17.5 & -2.0 & -1.9 & -0.3 & -24.6 & -21.5 & -21.0 \\
\hline Incoming shortwave radiation $\left(\mathrm{W} \mathrm{m}^{-2}\right)$ & 112.3 & 93.9 & 98.4 & 315.8 & 293.2 & 289.5 & 70.7 & 53.8 & 59.3 \\
\hline Wind speed $\left(\mathrm{m} \mathrm{s}^{-1}\right)$ & 2.8 & 2.5 & 3.7 & 4.0 & 2.8 & 4.6 & 2.5 & 2.4 & 3.5 \\
\hline Relative humidity (\%) & 77.9 & 72.2 & 64.1 & 68.2 & 67.3 & 52.2 & 79.9 & 73.1 & 66.5 \\
\hline
\end{tabular}
tends to only accumulate in hollows on the lake surfaces.

Table 1. Mean annual, summer (December-January) and winter (February-November) air temperature, wind speed, incoming solar radiation and degree-days above freezing at the Lake Fryxell (LF), Lake Hoare (LH) and Lake Bonney (LB) meteorological stations for 2010 (www.mcmlter.org) 


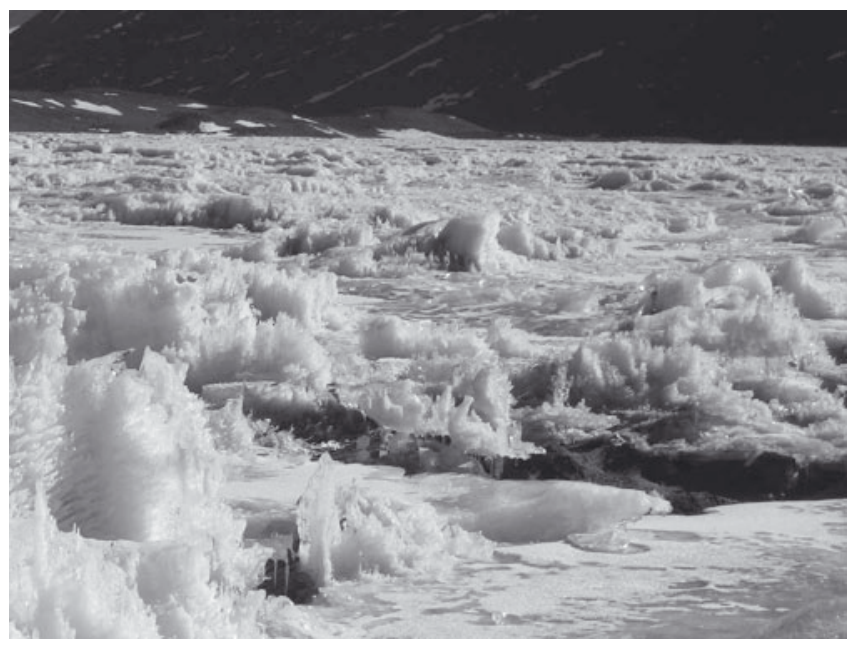

Fig. 2. Heavily ablated surface ice at Lake Hoare, December 2011. Note the dark sediment deposited in the hollows of the ice.

We do not have data to correlate the accumulation of snow at shoreline meteorological stations versus the middle of the lakes, and therefore do not include snowfall in our sublimation/ablation calculations. Snowfall likely has a minor impact on the long-term stage record at Lakes Hoare and Bonney due to mean precipitation rates of $<0.008 \mathrm{~m}$ w.e. $\mathrm{a}^{-1}$ (Fountain and others, 2010). At Lake Fryxell, our calculations may underestimate sublimation/ablation by $\sim 0.03 \mathrm{~m} \mathrm{a}^{-1}$ based on annual snow accumulation (Fountain and others, 2010). Lastly, melt at the bottom of the ice cover will increase the pressure reading of the hanging sensor as thinning ice is displaced downwards. In an Arctic lake, bottom melt has been shown to become significant only near the end of the melt season when the ice thins to $<1 \mathrm{~m}$ (Heron and Woo, 1994). Due to the thick ice cover on the Taylor Valley lakes, and limited heat transport by glacial/river inflow, we assume that bottom melt is negligible.

This paper presents ablation values, or the amount of ice that is lost from the surface of the lake ice throughout the year. In the winter, ablation is solely a result of sublimation, so the two variables are equal. In the summer, ablation represents the sum of sublimation and any surface melt, which is assumed to flow into the lake. All sublimation/ ablation values are presented in water equivalent. With simplifying assumptions and an ice:water density ratio of 0.91, our equations become:

\section{during winter:}

depth of moored transducer (stage) $=-$ sublimation

\section{during summer:}

depth of hanging transducer (ablation) $=-$ ablation/0.91

To compare seasonal trends, annual records were partitioned as summer or winter based on stage data. Using the longest continuous dataset, the onset of summer and winter was defined as the days of the year corresponding to the local minimum and maximum (turning points) in stage values at Lake Bonney (Fig. 4c). For example, summer 2007/ 08 is demarcated as 12 December-27 January, and summer 2008/09 as 9 December-30 January (Fig. 4d). From 2001 to 2010, the summer seasons range from 33 to 66 days in length (Table 2). In two instances (2003-04 and 2007), stage values were not available from Lake Bonney, and seasonal

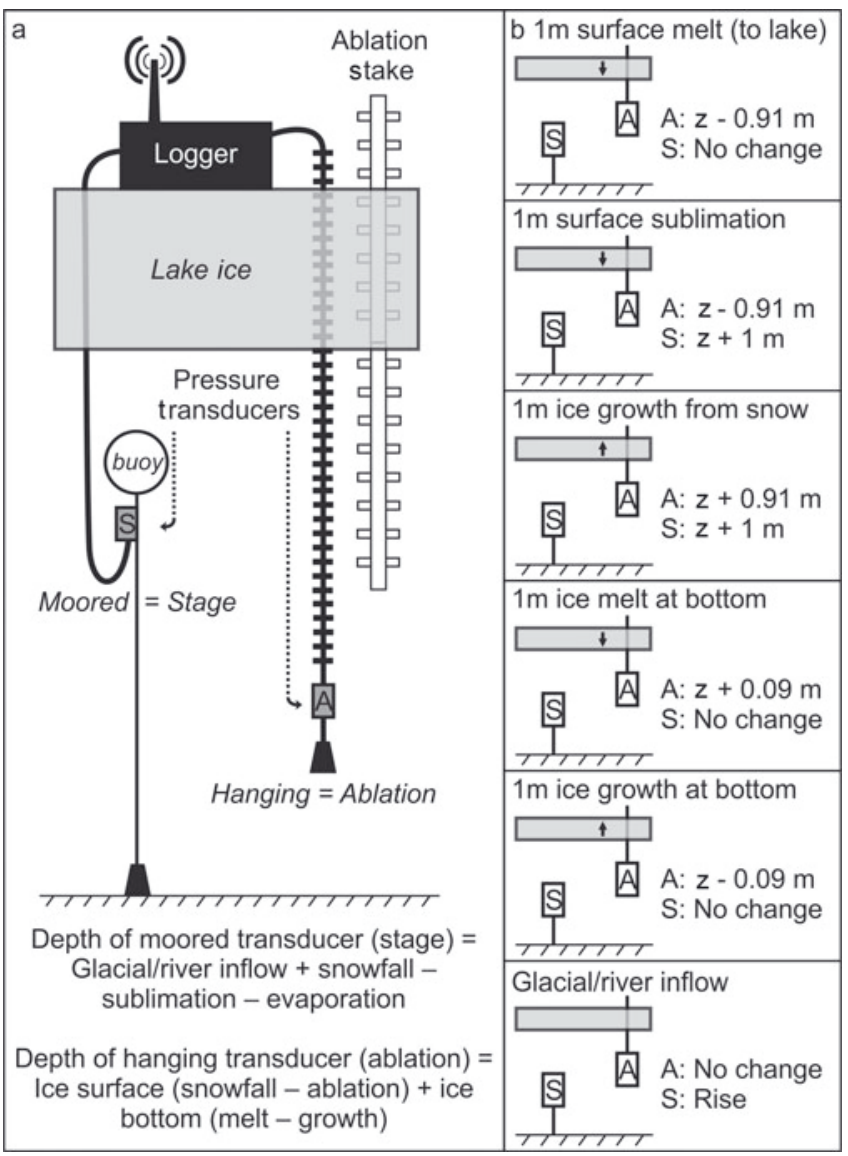

Fig. 3. (a) Set-up of data logger and sensors housed on the ice surface of each lake. The moored and hanging pressure transducers are used to calculate changes in stage and surface ice ablation, respectively, based on the equations given. (b) The depth output, $z$, of stage $(\mathrm{S})$ and ablation (A) pressure transducers based on a series of lake/ice perturbations. All values are given in water equivalent, and an ice:water density ratio of 0.91 is applied. Arrows represent movement of the ice cover due to the effects of buoyancy.

end points were based on data from Lakes Hoare and Fryxell. Daily sublimation rates from March to October were combined for all years and statistically compared between lakes using two-tailed $t$-tests for equal variance.

Manual ablation stakes were installed on the east, center and west sides of each lake in 1999. No more than two stakes existed at a given site concurrently. The stakes are vertically oriented PVC pipes with short $5 \mathrm{~cm}$ sections of Plexiglas rod mounted horizontally at $1 \mathrm{~m}$ intervals along the length of the stake to anchor it in the ice cover. Manual measurements, recorded as the annual difference in stake height, represent a combined measurement of winter and summer ablation and were not recorded on the same day every season. To facilitate comparison of manual measurements to automated data, the measurement interval was subdivided into the winter and summer seasons based on the previously defined dates. Summer ablation totals were calculated by applying winter ablation rates of $0.33,0.33$ and $0.53 \mathrm{~mm} \mathrm{~d}^{-1}$ for Lakes Fryxell, Hoare and Bonney, respectively, based on the low seasonal variability of the long-term stage record (Table 2). To compare the manual and automated ablation record over a 10 year period, we calculated the $z$-scores at each stake in each given year. The standardized values for each stake were then averaged over the length of the dataset. 


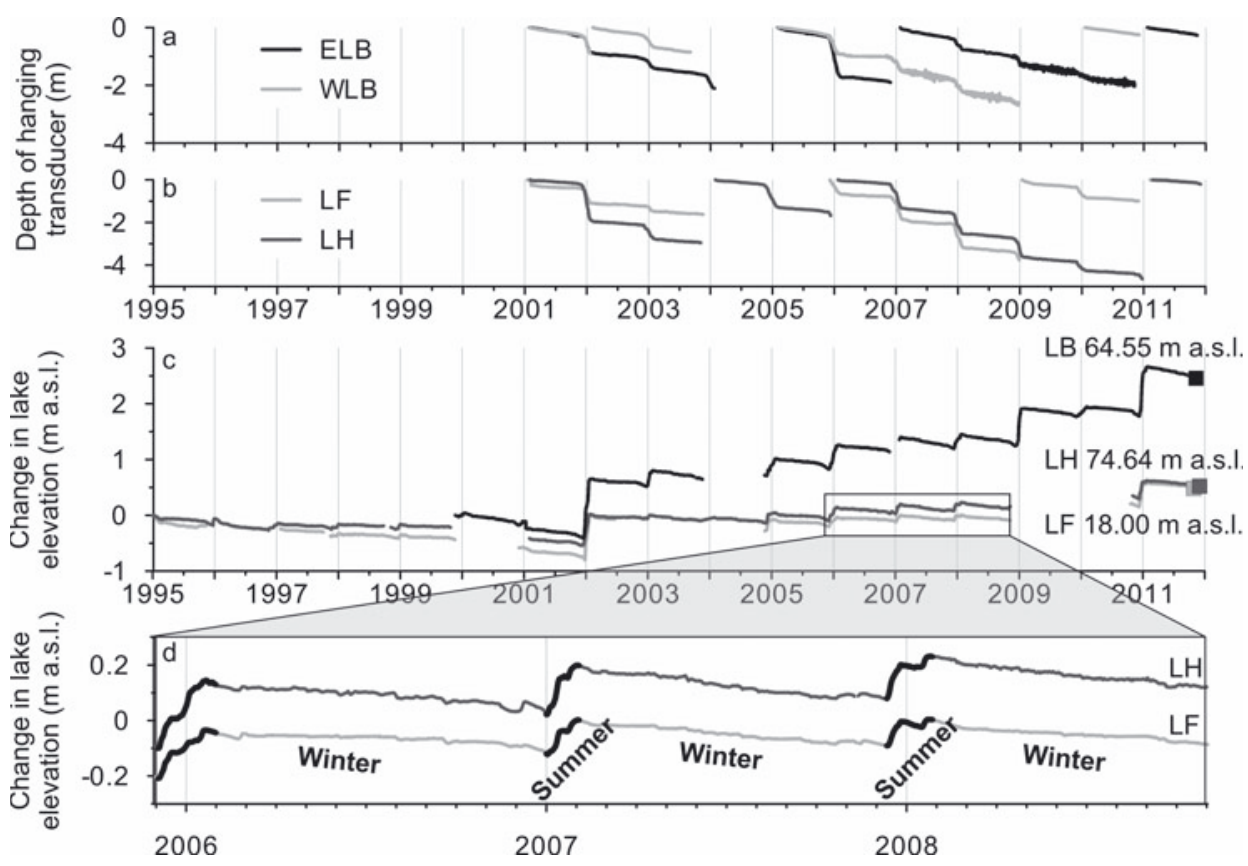

Fig. 4. (a, b) The relative change in depth of the hanging pressure transducer used to record surface ice ablation at Lake Fryxell (LF), Lake Hoare (LH) and Lake Bonney (LB). Ablation values are reset to a zero baseline following an extended sensor failure. The data become progressively noisier due to ageing sensors that were replaced in 2010 and 2011. (c) Lake levels based on water surface elevation. East Lobe and West Lobe Bonney are connected by an $11 \mathrm{~m}$ deep sill, and therefore register equivalent stage. Data are referenced against surveyed benchmarks, and 2011 lake elevations are presented as squares. The slight dips in elevation directly prior to annual lake level rise represent increased summer sublimation that precedes river discharge. (d) The inset depicts the demarcation of summer and winter seasons. Some of the small-scale variation noticeable in the winter may result from snow accumulation events.

The long-term stage record spans 1995-2011 for Lakes Hoare and Fryxell, and 2001-11 for East Lobe Bonney. Automated ablation values are available from 2001 to 2011. Pressure data were recorded every minute and averaged at 20 min intervals. In 2009, Campbell Scientific CR10X data loggers were replaced with CR1000 data loggers. Prior to 2010, ablation and stage were measured with Druck PDCR 1830 pressure transducers (accuracy $\pm 0.06 \%$ ) or Keller Series 173 pressure transducers (at Lake Hoare, accuracy $\pm 0.1 \%$ ). In 2010, pressure transducers on Lake Fryxell, Lake Hoare and East Lobe Bonney were replaced with Campbell Scientific CS455 pressure transducers (accuracy $\pm 0.1 \%$ ). Stage at West Lobe Bonney is equivalent to that of East Lobe
Bonney, and all pressure transducers are vented to the surface. In order to calibrate the automated stage measurements, lake levels were annually surveyed prior to, and near the end of, the summer melt, and are presented in ma.s.l. Due to the discrepancy between GPS measurements recorded as geoid elevations and elevations optically surveyed from the ocean, an offset is applied to current GPS data to match historic optical survey transects of Taylor Valley conducted by the New Zealand Antarctic Program in the 1960s (Chinn, 1993).

Meteorological data from 2010 are presented as an example of climate variability between the three lakes. Mean annual air temperature, wind speed and incoming

Table 2. Total summer ablation as calculated by a hanging pressure sensor installed in the ice cover, and total winter sublimation as calculated by the difference in maximum stage at the beginning of winter and minimum stage at the end of winter

\begin{tabular}{|c|c|c|c|c|c|c|c|c|}
\hline \multirow[t]{2}{*}{ Summer (days) } & \multicolumn{4}{|c|}{ Summer ablation } & \multirow[t]{2}{*}{ Winter (days) } & \multicolumn{3}{|c|}{ Winter sublimation } \\
\hline & $\begin{array}{l}\mathrm{LF} \\
\mathrm{m}\end{array}$ & $\begin{array}{c}\mathrm{LH} \\
\mathrm{m}\end{array}$ & $\begin{array}{c}\text { ELB } \\
\mathrm{m}\end{array}$ & $\begin{array}{c}\text { WLB } \\
\mathrm{m}\end{array}$ & & $\begin{array}{l}\mathrm{LF} \\
\mathrm{m}\end{array}$ & $\begin{array}{c}\mathrm{LH} \\
\mathrm{m}\end{array}$ & $\begin{array}{c}\mathrm{LB} \\
\mathrm{m}\end{array}$ \\
\hline 2000/01 (n/a) & & & & & 2001 (317) & 0.13 & 0.12 & 0.17 \\
\hline 2001/02 (52) & 0.67 & 1.62 & 0.58 & 0.60 & $2002(321)$ & & 0.07 & 0.14 \\
\hline 2002/03 (38) & 0.25 & 0.49 & 0.27 & 0.31 & $2003(292)$ & & 0.10 & 0.16 \\
\hline $2003 / 04(66)$ & & & 0.51 & & $2004(313)$ & & 0.09 & \\
\hline $2004 / 05(52)$ & & 0.93 & & & 2005 (315) & 0.13 & 0.14 & 0.19 \\
\hline 2005/06 (58) & 0.70 & & 1.41 & 0.68 & $2006(335)$ & 0.08 & 0.11 & 0.12 \\
\hline 2006/07 (33) & 0.81 & 0.78 & & 0.37 & 2007 (312) & 0.09 & 0.12 & 0.21 \\
\hline 2007/08 (46) & 1.10 & 0.95 & 0.38 & 0.38 & $2008(312)$ & 0.09 & 0.07 & 0.21 \\
\hline $2008 / 09$ (52) & 0.51 & 0.99 & 0.27 & & 2009 (306) & & & 0.15 \\
\hline $2009 / 10(63)$ & 0.54 & 0.45 & & & 2010 (309) & & & 0.17 \\
\hline Mean (2001-10) & 0.65 & 0.89 & 0.57 & 0.47 & Mean $(2001-10)$ & 0.10 & 0.10 & 0.17 \\
\hline
\end{tabular}

Mean annual ablation: LF $0.76 \mathrm{~m}$, LH $0.99 \mathrm{~m}$, ELB $0.74 \mathrm{~m}$, WLB $0.64 \mathrm{~m}$ 

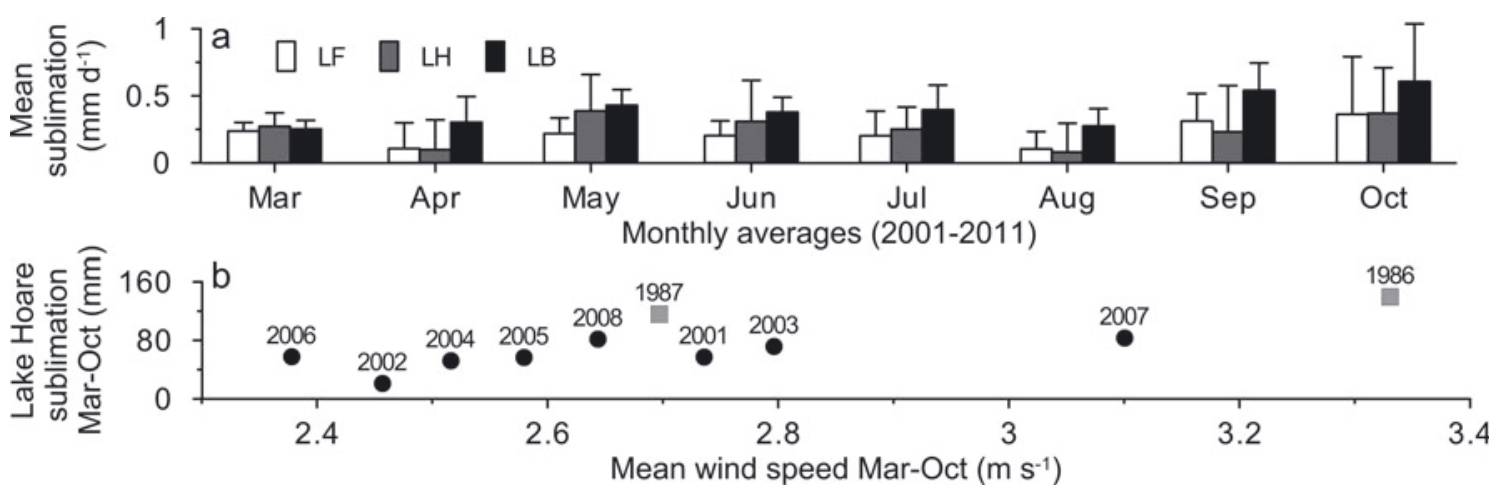

Fig. 5. (a) Monthly rates of winter sublimation at Lake Fryxell (LF), Lake Hoare (LH) and Lake Bonney (LB) averaged from 2001 to 2011 . Error bars represent one standard deviation between all monthly values for individual lakes (b) Black circles denote total sublimation from March to October at Lake Hoare plotted against mean wind speed. Gray squares represent modeled sublimation estimates at Lake Hoare from Clow and others (1988) for 1986 and 1987.

solar radiation are calculated from $15 \mathrm{~min}$ averages from meteorological stations located on the shorelines of Lake Fryxell, Lake Hoare and East Lobe Bonney, and have been in operation since 1987, 1985 and 1993, respectively (Fig. 1). A complete description of sensors and long-term averages is available in Doran and others (2002a).

\section{RESULTS}

Between 1 January 2001 and 1 January 2011, the levels of Lakes Bonney, Hoare and Fryxell rose by $2.6 \mathrm{~m}, 1.0 \mathrm{~m}$ and $1.0 \mathrm{~m}$, respectively (Fig. 4). The majority of annual variation in the water balance of the Taylor Valley lakes occurs during the summer as a result of gain from river and glacial input and loss from sublimation. During the winter, mean sublimation values are relatively constant from 2000 to 2010 at $0.33 \pm 0.08 \mathrm{~mm} \mathrm{~d}^{-1}$ for Lake Fryxell, $0.33 \pm 0.08$ $\mathrm{mm} \mathrm{d}^{-1}$ for Lake Hoare, and $0.53 \pm 0.11 \mathrm{~mm} \mathrm{~d}^{-1}$ for Lake Bonney ( \pm 1 std dev.). This amounts to $0.10 \mathrm{~m}, 0.10 \mathrm{~m}$ and $0.17 \mathrm{~m}$ of average winter sublimation for the three lakes (Table 2). Lake Bonney has a significantly higher daily sublimation rate from March to October than either Lake Hoare or Lake Fryxell ( $t$-test, $p<0.01$; Fig. 5a). Winter sublimation rates are compared to those modeled by watervapor mass flux equations at Lake Hoare, and plotted against mean wind speed (Fig. 5b; Clow and others, 1988). Overall, the average March-October sublimation rate of $0.24 \mathrm{~mm} \mathrm{~d}^{-1}$ at Lake Hoare is lower than the modeled rate of $0.52 \mathrm{~mm} \mathrm{~d}^{-1}$ (Clow and others, 1988).

Summer ablation values are much more variable, and

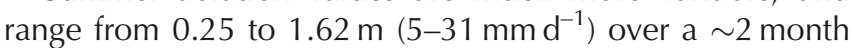
period (Table 2). In 2001/02, summer ablation was substantially higher at Lake Hoare than at the other lakes, and likewise in 2005/06 at East Lobe Bonney. The lake stations are located adjacent to the central ablation stakes at Lakes Fryxell and Bonney, and adjacent to the east ablation stake at Lake Hoare (Fig. 1). Manual ablation readings match or underestimate total summer ablation as recorded by the hanging pressure transducer, and in no year does the manual ablation reading markedly exceed the automated value (see Fig. 6a). We hypothesize that our underestimation results from stakes periodically slipping downward in the ice. Any downward movement of the hanging transducer would be clearly noticeable in the pressure data, so we take the automated data as the more accurate of the two measurements. Due to errors and missing data in the manual record, only data from
2001/02 are plotted with absolute values of ablation (Fig. 6a). Along the length of the valley, there is no significant spatial trend in summer ablation as recorded by the ablation stakes; nevertheless, it is important to note that, on average, the highest summer ablation occurs at Lake Hoare, and on the west end of Lake Bonney which abuts Taylor Glacier (Fig. 6b).

\section{DISCUSSION}

Sublimation rates can be modeled by the latent heat flux emanating from the ice cover into the atmosphere. Two critical variables in this calculation are wind speed, and the vapor pressure difference above and at the ice surface, which corresponds to air and ice surface temperature (Brock and Arnold, 2000; Bliss and others, 2011). In Taylor Valley, climate is significantly influenced by westerly winds that descend from Taylor Dome. This is especially evident between June and August, when high wind speeds result in average temperature increases of $\sim 17^{\circ} \mathrm{C}$ and lowering of relative humidity by $25 \%$ during katabatic events (Nylen and others, 2004). Consequently, it was expected that Lake Bonney, which is situated at the base of Taylor Glacier and experiences a higher mean annual wind speed (Table 1) and higher frequency of $>4 \mathrm{~m} \mathrm{~s}^{-1}$ winter winds (Doran and others, 2002a) than either Lake Hoare or Lake Fryxell, would have the highest rates of winter sublimation. Results confirm that winter sublimation averages $0.17 \mathrm{~m}$ at Lake Bonney and only $0.10 \mathrm{~m}$ at the other two lakes (Table 2 ).

The major difficulty in elucidating the driver of summer ablation is to predict the effect of incoming solar radiation on the surface temperature of the ice cover, as the spatial heterogeneity of surface albedo unequally warms the ice surface. Patches of sediment deposited on the ice cover during windy periods warm the surface by absorbing a much higher proportion of solar radiation than that of a clean ice surface. Beach sand deposited on the lakes has an albedo of only 0.1-0.15 (McKay and others, 1994; Jepsen and others, 2010), much lower than that of smooth ice, measured at 0.2-0.4 at Lake Hoare and nearby Lake Vanda, and that of angular late-summer ice, which can have an albedo of 0.6 (Goldman and others, 1967; McKay and others, 1994). Elevated surface temperatures permit a larger vapor pressure difference and, therefore, rate of ablation. Moreover, this process is a positive feedback. Variable ablation due to heterogeneous sediment deposition produces hollows in the ice cover which in turn can alter wind and temperature 

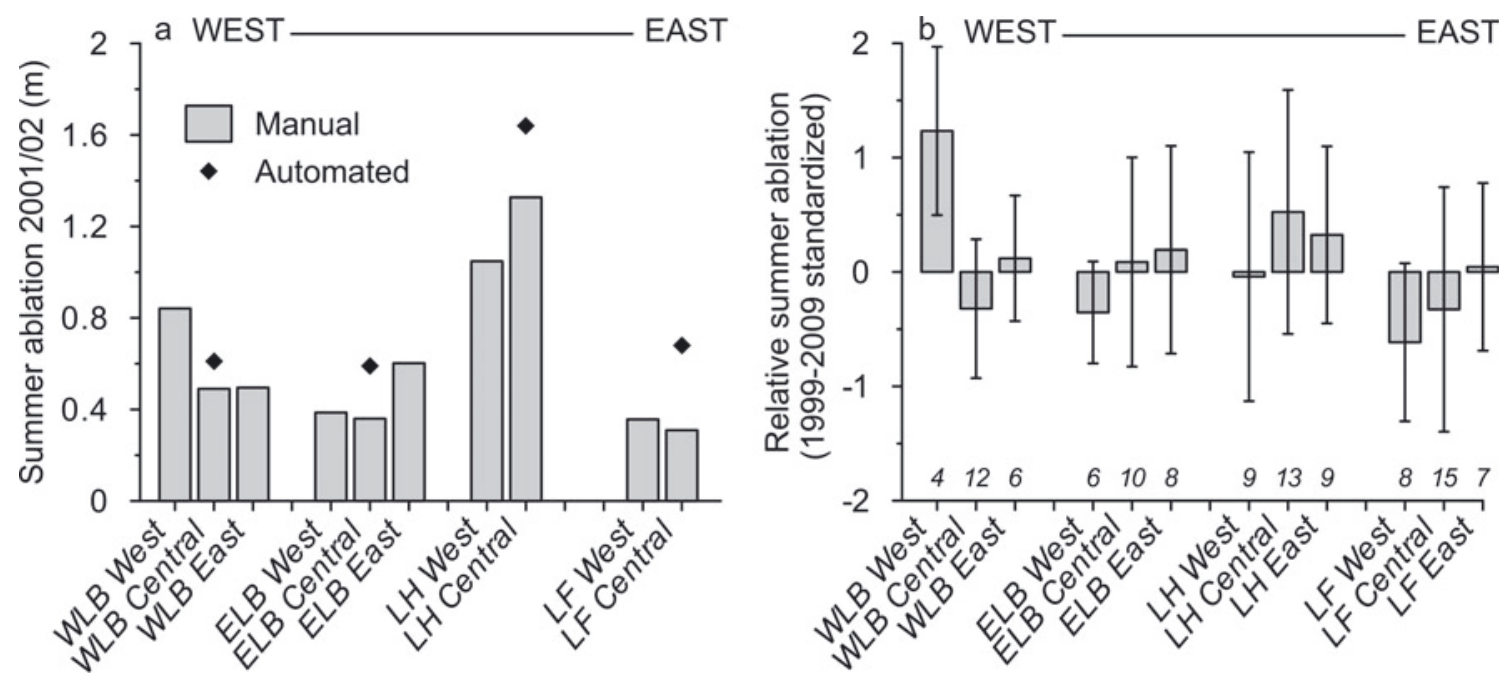

Fig. 6. (a) 2001/02 summer ablation recorded at individual ablation stakes in the western, central and eastern portions of the three lakes. Automated data collected at stations adjacent to 'central' stakes are plotted as black diamonds. (b) Spatial variation in summer ablation measurements at manual ablation stakes from 1999 to 2009. To standardize, $z$-scores of summer ablation values were calculated for each stake in each given year and then averaged over the length of the dataset. Error bars correspond to the standard deviation of all data at one location. Values along the $x$-axis signify the number of data points included in the average, as some years had two ablation stakes present, while other years are missing data.

patterns at the ice surface and promote greater ablation (Jepsen and others, 2010).

Our study found that total summer ablation, while extremely variable, was often greatest at Lake Hoare. There is no singular climatological factor that accounts for this trend, unlike in winter, when katabatic events strongly control the rate of sublimation. It is hypothesized that the high rates of summer ablation at Lake Hoare are a result of sediment loading on the ice cover, and are not due to enhanced solar radiation (Table 1). The Lake Hoare basin is the smallest and narrowest of the three basins, and is enclosed by Seuss and Canada Glaciers. Aeolian sedimentation input is highest at Lake Hoare (Šabacká and others, 2012), and it may be that once sediment is deposited on the ice cover it is less mobile than at the other lakes where wide basin floors do not restrict near-surface winds. Likewise, Lake Bonney typically has the lowest summer ablation while averaging the highest number of degree-days above freezing (Table 1). It may be that high winds can effectively redistribute sediment and smooth the ice surface, which reduces the energy flux to the ice and lowers the surface temperature. On West Lobe Bonney, the higher rates of summer ablation on the western edge may originate from high winds descending immediately off the face of Taylor Glacier. Also, the western edge of the lake typically has a larger volume of surface sediment, which would act to decrease albedo and warm the surface layer. Similarly, the western edge of East Lobe Bonney, which has lower rates of summer ablation, is sheltered in the lee of Bonney Riegel, a large bedrock feature that likely impedes westerly winds. Unfortunately, no estimates of percent debris cover exist for the three lakes. Field observations and satellite imagery of the lakes confirm that Lake Hoare, in most years, has the roughest and most sediment-laden ice cover, whereas Lake Bonney has the flattest, cleanest ice.

Near the terminus of Taylor Glacier, annual ablation has been measured at $0.44 \mathrm{~m}$ w.e. (Robinson, 1984), $0.34 \mathrm{~m}$ w.e. (Fountain and others, 2006), $0.18 \mathrm{~m}$ w.e. (Hoffman and others, 2008) and 0.20 mw.e. (Bliss and others, 2011).
Winter and summer ablation rates were found to be $0.17 \mathrm{~mm} \mathrm{~d}^{-1}$ and $1.09 \mathrm{~mm} \mathrm{~d}^{-1}$, respectively, using an estimate of latent heat flux based on meteorological variables (Bliss and others, 2011). These values are lower than those measured at Lake Bonney, which is expected as the lake is situated $267 \mathrm{~m}$ lower and averages more positive degree-days (1993-2000 average $=34$.3; Doran and others, 2002a) than those recorded at the meteorological station on Taylor Glacier (1995-2006 average = 4.7; Hoffman and others, 2008).

In an environment where temperatures exceed $0^{\circ} \mathrm{C}$ for $<2$ months, atypical meteorological conditions can lead to extreme hydrological responses (Barrett and others, 2008; Doran and others, 2008). The highest summer ablation of $1.62 \mathrm{~m}$ w.e. was recorded during the anomalously warm summer of 2001/02 (Doran and others, 2008), yet only at Lake Hoare was ablation markedly high. The annual ablation values recorded from 2001 to 2010 are generally much higher than the commonly quoted value of $0.3-$ $0.4 \mathrm{~m} \mathrm{a}^{-1}$ for Taylor Valley, which was derived from physical measurements of the ice ablation at Lake Fryxell (Henderson and others, 1966), and from a sublimation model based on the climate record at Lake Hoare in 1986 and 1987 (Clow and others, 1988). Our annual ablation values only approach $0.3 \mathrm{ma}^{-1}$ in the lowest years, and never at Lake Hoare. Our data better correspond to the $1.5 \mathrm{ma}^{-1}$ documented at Lake Hoare based on the migration time of five corks released below the ice cover and allowed to ablate to the surface (Simmons and others, 1986).

Ablation values are often incorporated into ice thickness models (McKay and others, 1985) and used to determine the residence times of water and gases in the dry-valley lakes (Wharton and others, 1989). In Taylor Valley, where ice thicknesses range from 3 to $6 \mathrm{~m}$, our dataset proves that a $3 \mathrm{~m}$ ice cover will turn over in 3-5 years if average ablation is quoted between 0.6 and $1.0 \mathrm{ma}^{-1}$. This is twice the previously assumed rate (Clow and others, 1988), and has important ramifications for sediment dynamics in the ice cover, and gas and solute exclusion processes. In the 
permanent ice covers, a microbial ecosystem exists in association with sediment particles (Fritsen and Priscu, 1998; Paerl and Priscu, 1998; Priscu and others, 1998, 2005). In Lakes Bonney and Hoare, a dominant peak in sediment concentration and chlorophyll a exists at $2 \mathrm{~m}$ depth, and ranges from 0.5 to $3 \mathrm{~m}$ across the dry-valley lakes, as sediment migrates downward in the ice cover (Fritsen and Priscu, 1998; Priscu and others, 1998). Modeled cycles of sediment movement show a decrease in maximum depth and an increase in annual depth variance of the sediment peaks with increased ablation (Jepsen and others, 2010). This repetitive cycle of upward ablation of the ice cover and descent through ice melt may promote the coalescing of sediment into larger pockets and enhance melt migration. Higher ablation rates would also more quickly replenish surface ice that has undergone morphological changes, such as 'ice-whitening', which limits the transmission of photosynthetically active radiation through the ice cover (Fritsen and Priscu, 1999).

\section{CONCLUSIONS}

To our knowledge, this dataset is the first long-term ablation record from lake ice. In the past, empirical measurements were limited to annual or summer values. We find that summer ablation is the major driver of ice loss and can vary from $0.25 \mathrm{~m}$ to $1.62 \mathrm{~m}$ in warm years, whereas winter sublimation accounts for only $0.07-0.21 \mathrm{~m}$ of ice loss. Along Taylor Valley, annual ablation is highest at Lake Hoare, which we hypothesize is a result of sediment loading on the ice cover. Sublimation is the main mechanism of water loss in closed-basin, perennially ice-covered lakes. With accurate ablation data we are one step closer to closing the water balance of the dry-valley lakes and understanding the climatic variables that control water routing. The next objective will be to use the high-resolution pressure data to validate summer sublimation models, such as that used by Clow and others (1988), in order to calculate total water loss from the lakes. Ultimately, sublimation values will be input into a whole-lake water balance to establish the direct glacial discharge entering the lakes, which is currently unknown.

\section{ACKNOWLEDGEMENTS}

We thank all the field members who contributed to this project, including Jennifer Lawson, Phil Allen and Miroljub Medved, as well two reviewers whose comments greatly improved the manuscript. GPS support was provided by UNAVCO. This research was funded by the US National Science Foundation (NSF) Office of Polar Programs (grants 9810219, 0423595, 0096250, 0832755, 1041742 and 1115245)

\section{REFERENCES}

Barrett JE and 6 others (2008) Persistent effects of a discrete warming event on a polar desert ecosystem. Global Change Biol., 14(10), 2249-2261 (doi: 10.1111/j.1365-2486.2008.01641.x)

Bliss AK, Cuffey KM and Kavanaugh JL (2011) Sublimation and surface energy budget of Taylor Glacier, Antarctica. J. Glaciol., 57(204), 684-696 (doi: 10.3189/002214311797409767)

Box JE and Steffen K (2001) Sublimation on the Greenland ice sheet from automated weather station observations. J. Geophys. Res., 106(D24), 33 965-33 981 (doi: 10.1029/2001JD900219)

Brock BW and Arnold NS (2000) A spreadsheet-based (Microsoft Excel) point surface energy balance model for glacier and snowmelt studies. Earth Surf. Process. Landf., 25(6), 649-658 (doi: 10.1002/1096-9837(200006)25:6<649::AID-ESP97>3.0. $\mathrm{CO} ; 2-\mathrm{U})$

Cartwright K and Harris HJH (1981) Hydrogelogy of the dry valley region, Antarctica. In McGinnis LD ed. Dry Valley Drilling Project (Antarct. Res. Ser. 33) American Geophysical Union, Washington, DC, 193-214

Chinn TJ (1993) Physical hydrology of the Dry Valley lakes. In Green WJ and Friedmann El eds. Physical and biogeochemical processes in Antarctic lakes. (Antarctic Research Series 59) American Geophysical Union, Washington, DC, 1-51

Clow GD, McKay CP, Simmons GM, Jr and Wharton RA, Jr (1988) Climatological observations and predicted sublimation rates at Lake Hoare, Antarctica. J. Climate, 1(7), 715-728 (doi: 10.1175/ 1520-0442(1988)001<0715:COAPSR >2.0.CO;2)

Doran PT, Wharton RA, Jr and Lyons WB (1994) Paleolimnology of the McMurdo Dry Valleys, Antarctica. J. Paleolimnol., 10(2), 85-114 (doi: 10.1007/BF00682507)

Doran PT and 12 others (2002) Antarctic climate cooling and terrestrial ecosystem response. Nature, 415(6871), 517-520

Doran PT and 6 others (2002) Valley floor climate observations from the McMurdo dry valleys, Antarctica, 1986-2000. J. Geophys. Res., 107(D24), 4772 (doi: 10.1029/2001JD002045)

Doran PT and 6 others (2008) Hydrologic response to extreme warm and cold summers in the McMurdo Dry Valleys, East Antarctica. Antarct. Sci., 20(5), 499-509 (doi: 10.1017/ S0954102008001272)

Fountain AG, Nylen TH, MacClune KL and Dana GL (2006) Glacier mass balances (1993-2001), Taylor Valley, McMurdo Dry Valleys, Antarctica. J. Glaciol., 52(178), 451-462 (doi: 10.3189/ $172756506781828511)$

Fountain AG, Nylen TH, Monaghan A, Basagic HJ and Bromwich D (2010) Snow in the McMurdo Dry Valleys, Antarctica. Int. J. Climatol., 30(5), 633-642 (doi: 10.1002/joc.1933)

Fritsen $\mathrm{CH}$ and Priscu JC (1998) Cyanobacterial assemblages in permanent ice covers on Antarctic lakes: distribution, growth rate and temperature response of photosynthesis. J. Phycol., 34(4), 587-597 (doi: 10.1046/j.1529-8817.1998.340587.x)

Fritsen $\mathrm{CH}$ and Priscu JC (1999) Seasonal change in the optical properties of the permanent ice cover on Lake Bonney, Antarctica: consequences for lake productivity and phytoplankton dynamics. Limnol. Oceanogr., 44(2), 447-454

Goldman CR, Mason DT and Hobbie JE (1967) Two Antarctic desert lakes. Limnol. Oceanogr., 12(2), 295-310

Henderson RA, Prebble WM, Hoare RA, Popplewell KB, House DA and Wilson AT (1966) An ablation rate for Lake Fryxell, Victoria Land, Antarctica. J. Glaciol., 6(43), 129-133

Heron R and Woo MK (1994) Decay of a High Arctic lake-ice cover: observations and modelling. J. Glaciol., 40(135), 283-292

Hoffman MJ, Fountain AG and Liston GE (2008) Surface energy balance and melt thresholds over 11 years at Taylor Glacier, Antarctica. J. Geophys. Res., 113(F4), F04014 (doi: 10.1029/ 2008JF001029)

Jepsen SM, Adams EE and Priscu JC (2010) Sediment melt-migration dynamics in perennial Antarctic lake ice. Arct. Antarct. Alp. Res., 42(1), 57-66

McKay CP, Clow GD, Wharton RA and Squyres SW (1985) Thickness of ice on perennially frozen lakes. Nature, 313(6003), 561-562 (doi: 10.1038/313561a0)

McKay CP, Clow GD, Andersen DT and Wharton RA, Jr (1994) Light transmission and reflection in perennially ice-covered Lake Hoare, Antarctica. J. Geophys. Res., 99(C10), 20 427-20 444

Monaghan AJ, Bromwich DH, Powers JG and Manning KW (2005) The climate of the McMurdo, Antarctica, region as represented by one year of forecasts from the Antarctic mesoscale prediction system. J. Climate, 18(8), 1174-1189 (doi: 10.1175/JCLI3336.1)

Nylen TH, Fountain AG and Doran PT (2004) Climatology of katabatic winds in the McMurdo Dry Valleys, southern Victoria 
Land, Antarctica. J. Geophys. Res., 109(D3), D03114 (doi: 10.1029/2003JD003937)

Paerl HW and Priscu JC (1998) Microbial phototrophic, heterotrophic, and diazotrophic activities associated with aggregates in the permanent ice cover of Lake Bonney, Antarctica. Microbial Ecol., 36(3-4), 221-230 (doi: 10.1007/s002489900109)

Priscu JC and 9 others (1998) Perennial Antarctic lake ice: an oasis for life in a polar desert. Science, 280(5372), 2095-2098 (doi: 10.1126/science.280.5372.2095)

Priscu JC and 7 others (2005) Perennial Antarctic lake ice: a refuge for cyanobacteria in an extreme environment. In Castello JD and Rogers SO eds. Life in ancient ice. Princeton University Press, Princeton, NJ, 22-49

Robinson PH (1984) Ice dynamics and thermal regime of Taylor Glacier, South Victoria Land, Anatarctica. J. Glaciol., 30(105), 153-160
Šabacká M and 6 others (2012) Aeolian flux of biotic and abiotic material in Taylor Valley, Antarctica. Geomorphology, 155-156, 102-111 (doi: 10.1016/j.geomorph.2011.12.009)

Simmons GM, Jr, Wharton RA, Jr, McKay C, Nedell SS and Clow GD (1986) Sand/ice interactions and sediment deposition in perennially ice-covered Antarctic lakes. Antarct. J. US, 21(5), 217-220

Squyres SW, Andersen DW, Nedell SS and Wharton RA, Jr (1991) Lake Hoare, Antarctica: sedimentation through a thick perennial ice cover. Sedimentology, 38(2), 363-379 (doi: 10.1111/j.13653091.1991.tb01265.x)

Wharton RA, McKay CP and Simmons GM, Jr (1989) Perennially ice-covered Lake Hoare, Antarctica: physical environment, biology and sedimentation. Hydrobiologia, 172(1), 306-320 (doi: 10.1007/BF00031629)

Woo MK (1980) Hydrology of a small lake in the Canadian High Arctic. Arct. Alp. Res., 12(2), 227-235

MS received 10 April 2012 and accepted in revised form 12 December 2012 